\title{
WATER HARVESTING - TWO YEARS' EXPERIENCE ON NO. 4 DAIRY, MASSEY UNIVERSITY
}

\section{Kevin I. Lowe}

Agricultural Economics and Farm Management Deparfmenf, Mussey University. Palmerston N orth

\section{Abstract}

The water harvesting concept offers the potential for irrigation which may be considered in the absence of a cheaper and less limited water source. Because of high capital costs and storage limitations, it would not be a viable financial proposition for many grassland farmers. It may, however, have a place for a specific purpose such as the production of high value crops.

\section{INTRODUCTION}

No. 4 Dairy is a seasonal supply dairy farm situated on the terrace country behind Massey University, milking 360 cows on 150 ha. The soil type is Tokomaru silt loam, a glacial yellowgrey earth with poor natural drainage. The district is typified by soil moisture deficits in summer and a water surplus in winter and early spring.

As part of a research project to investigate the water harvesting concept a series of three dams was constructed in a watercourse. The dams are filled from a 25 ha catchment through a tile and mole drainage system.

It must be emphasized that the system is a pilot project and was never designed specifically to cope with the whole-farm summer problem.

\section{EVALUATION OF IRRIGATION SYSTEMS}

The evaluation of any irrigation system is a complex matter because, although capital and running costs may be readily available, putting a value on any irrigation response is usually very difficult.

This means that general statements about the profitability of irrigation have real shortcomings, and in any case will relate to particular circumstances of season, irrigation strategy, type of crop or pasture receiving water, and how it is utilized. 
In this brief paper, it is only intended to discuss some particular aspects of irrigating from dams.

\section{IRRIGATION STRATEGY}

With an unlimited water source such as a stream or a deep well, a farmer with irrigation equipment in his shed will start irrigating as soon as a moisture deficit is apparent and will normally irrigate as big an area as his equipment will allow.

With a water harvesting system, the farmer is faced with a limited water supply, which will diminish after spring because of evaporation and seepage from the dams. His irrigation strategy here must be to make best use of the available water. Decisions are made more difficult by seasonal uncertainty. The water source at No. 4 may be sufficient to solve water stress problems in pasture over perhaps 10 ha for an extended dry season such as $1974-5$, or 30 ha in a wetter season such as 1976-7, and the decision concerning the area to irrigate may have to be made as early as November when a moisture stress first develops.

If the area chosen is large and an extended dry spell arrives, the water supply will be quickly exhausted. If the area chosen is small and the dry spell turns out to be a short one, water will be unused and wasted. This we have found to be a real dilemma.

\section{STORAGE CAPACITY}

On a dairy farm such as No. 4 it is difficult to conceive of a situation where sufficient water could be stored to irrigate enough pasture on the farm to have a meaningful impact on the herd's production.

It has been suggested (Pow and Stewart, 1975) that 0.2 ha of irrigated pasture per milking cow may be adequate through the dry season. Applied to the No. 4 Dairy situation and assuming the application of $250 \mathrm{~mm}$ of water, this would require at least $200000 \mathrm{~m}^{3}$ of water stored. Based on the present system a tenfold increase in storage would be required, with 25 ha or $15 \%$ of the farm area unavailable for grazing. In any case appropriate dam sites for storage of this magnitude simply do not exist on No. 4.

Given, then, that the water harvesting concept offers a relatively small volume of water for irrigation, what place might it have?

Such things as high value crops in a situation where there is no other water source are obvious examples. But it might be that, even in a 'seasonal dairying situation, the opportunity for irriga- 
tion on a limited scale is worth considering for specific pur$\mathrm{p}$ o s e s.

For the last two seasons a greenfeed maize crop has been grown on No. 4 to assist with summer management. Being able to irrigate has allowed us to consider later planting and yet have an assured crop establishment (Lowe and Halford, 1975).

A second alternative is to irrigate a small area of pasture for young stock. Recent dry summers have led to problems with small young stock and a relatively small area of irrigated pasture has provided some security against this. However, one study of the No. 4 system (Inderbitzen, 1975) has shown that this problem can be overcome more cheaply with purchased feed.

\section{PRACTICAL POINTS}

Some benefits of the scheme are hard to estimate. What is the vaiue of a secure feed source on the farm for young stock? How important is the knowledge that a late-planted summer crop will get a good start? Some might also argue for aesthetic benefits. A series of dams can be very attractive - even if they have been pumped dry by duck-shooting time.

Some practical problems that have arisen are

(1) Drawing water from several sources requires a portable pump or very expensive electricity reticulation. A portable diesel pump like the one we have, with the necessary instrumentation, trailer and hand shift spray lines, is capable of irrigating a total of 30 ha if adequate water is available. Yet the current cost of this system is $\$ 12000$ to $\$ 15000$. In addition, diesel is three to four times more expensive than electricity as a power source, although the dieseldriven pump is much more flexible in use. The capital cost of dam construction, with the necessary fencing and dam protection, can also be high.

(2) Piping water long distances is difficult and expensive so any irrigation is really restricted to areas near the dams. If crops are being irrigated, this limits the crop rotation. If pasture is being irrigated for young stock, using the same land each year can lead to parasite problems.

(3) If dams are deep, most high-capacity pumps have problems with suction lift and the last few metres of water are difficult to utilize. Shallow dams, on the other hand, lead to large land areas being flooded, with high evaporation losses. 


\section{REFERENCES}

Inderbitzen, T, 1975. Irrigation on No. 4 Dairy Farm, Massey University, from the Wैater Harvesting D ams. Unpublished honours thesis.

Lowe, K. I.; Halford, R. E., 1975. Is it profitable to plan for a drought? Massey D airyjmg A.: 51-7.

Pow, K. D.; Stewart, I. D., 1975. Irrigation on pasture - does it pay? Massey Dairyjmg A.: $40-5$. 